\title{
In Vitro Simulation of Human Colonic Fermentation: A Practical Approach towards Models' Design and Analytical Tools
}

\author{
Elena Veintimilla-Gozalbo ${ }^{1}$, Andrea Asensio-Grau ${ }^{1, *}$, Joaquim Calvo-Lerma ${ }^{1,2}$, Ana Heredia 1 \\ and Ana Andrés 1 (D) \\ 1 Instituto de Ingeniería de Alimentos para el Desarrollo, Universitat Politècnica de València, \\ 46022 València, Spain; elveigo@alumni.upv.es (E.V.-G.); joaquim_calvo@iata.csic.es (J.C.-L.); \\ anhegu@tal.upv.es (A.H.); aandres@tal.upv.es (A.A.) \\ 2 Spanish National Research Council (IATA-CSIC), Institute of Agrochemistry and Food Technology, \\ 46980 València, Spain \\ * Correspondence: anasgr@tal.upv.es
}

Citation: Veintimilla-Gozalbo, E.; Asensio-Grau, A.; Calvo-Lerma, J.; Heredia, A.; Andrés, A. In Vitro Simulation of Human Colonic Fermentation: A Practical Approach towards Models' Design and Analytical Tools. Appl. Sci. 2021, 11, 8135. https://doi.org/10.3390/app 11178135

Academic Editors: Ester Betoret, Noelia Betoret and Leonel Pereira

Received: 30 July 2021

Accepted: 29 August 2021

Published: 2 September 2021

Publisher's Note: MDPI stays neutral with regard to jurisdictional claims in published maps and institutional affiliations.

Copyright: (c) 2021 by the authors. Licensee MDPI, Basel, Switzerland. This article is an open access article distributed under the terms and conditions of the Creative Commons Attribution (CC BY) license (https:// creativecommons.org/licenses/by/ $4.0 /)$.

\begin{abstract}
The human colonic microbiota plays an important role in the food digestion process and has a key role in maintaining health status. This community of microbes is inter-individually different due to several factors that modulate its composition. Among them, diet is one of the most relevant, which, in turn, is affected by environmental, economic, and cultural considerations. These pieces of evidence have promoted the study of the influence of diet on gut microbiota and the development of in vitro models that simulate the colonic digestion of foods. This narrative review aims to present a technical approach of the in vitro gut models available to evaluate the impact of diet on human colonic microbiota. A description and comments on the main characteristics, parameters, applicability, faecal inoculum preparation, and analytical tools are made. Despite the progress of in vitro colonic digestion models and metaomic applicability in this research field, there are still some challenges to face due to the lack of a consensus on the methodologies to conduct in vitro colonic digestions and the need to integrate the metaomic data to fully understand the influence of food in human colonic microbiota.
\end{abstract}

Keywords: human colonic microbiota; diet; in vitro colonic fermentation; in vitro dynamic digestion models; faecal inoculum; metaomic

\section{Introduction}

The role of diet in human health has been repeatedly addressed and confirmed. However, elucidating the relationship between nutrition and health requires an accurate understanding of the digestion process through which foods are transformed and interact with the organism to exert their eventual biological function [1].

Along digestion, chemical and enzymatic reactions, along with mechanical forces, transform food matrices and their main macronutrients (lipids, protein, and carbohydrates) into their conforming constituents, which are absorbed by the enterocytes in the small intestine [1]. Digestion is a very efficient process, but a small fractions of food constituents still escape the hydrolytic action of enzymes and subsequent absorption, thus remaining in the lumen and passing to the colonic stage, where the colonic microbiota can further interact with them, forming what is considered to be a relevant research topic nowadays [2-4].

Studying the digestion process in situ presents several vicissitudes due to the issue of access to the digestive system, the impossibility of continuous monitoring, and burden for the subjects as well as ethical restrictions [5]. Animal models have been extensively applied to assess the digestion process, but the fact that animals' microbiota differ from humans' microbiota is widely accepted [6]. For these reasons, alternative methodologies to study digestion have increased, including in vitro digestion models, which enable the 
simulation of digestion in the laboratory [7-10]. These models allow for the possibility of sampling at any point of the process, assessing digestion of any food or nutrient and establishing its effect on the microbiota profile, or determining the products generated by the microbiota metabolism [7,11]. In vitro digestion studies address such diverse research questions as macronutrient digestibility, bioactive compounds bioaccessibility, the release of encapsulated substances, or the effect of gastrointestinal conditions on digestibility, among others.

In relation to the microbiota, these models can be useful to assess the effect of prebiotics (nutritional compounds present in foods, such as fibres), probiotics (ingestion of alive microorganisms), or symbiotics (a combination of both) on microbiota populations or the role of these populations in the production of metabolites related to diet. Other relevant fields that could benefit from applying in vitro colonic fermentation relate to microbiota transmission from mothers to infants through breastmilk, the effect of antibiotics in the area of pharmacology, or in agronomics to determine if the presence of pesticides in some foods were to be evaluated in colonic microbiota. Depending on the goals, the digestion and fermentation variables must be adapted to represent the physiological conditions to simulate [5], such as transit time, $\mathrm{pH}$, digestive secretions and composition [10], or microbiota profile [12]. Compared to the standard digestion and fermentation conditions, these amendments are crucial in the context of food digestion studies in chronic disease (pancreatic insufficiency, celiac disease, etc.), special physiological states such as pregnancy, or life stages (infancy, adulthood, elderly).

Great efforts are being made by the scientific community to standardize in vitro protocols for mimicking the luminal digestion of foods $[13,14]$. Thanks to the adherence of many researchers to these protocols, which establish the basic characteristics that should be considered in the process (e.g., duration, $\mathrm{pH}$ of the stages, concentration of salts, and digestive enzymes), the comparison of results and the progress towards establishing general knowledge has been enabled. However, despite this progress, the in vitro simulation of the colonic stage still remains without a common consensus, probably because of the underpinning complexity to the reproduction of a microbial population and to all of the factors involved.

For these reasons, this narrative review aims to display a technical approach to the in vitro gut models available, which have been used in the food science and technology fields over the last 10 years to evaluate the impact of diet on the human colonic microbiota. In general terms, a description and comments on the main characteristics, parameters, applicability, faecal inoculum preparation, and analytical tools are provided.

\section{Materials and Methods}

Scopus was selected as the database due to its large quantity of information and its constant updating. First, the following words were used as keywords: in vitro gut fermentation or in vitro gut model and food. Additionally, two filters were added: a date range from 2010 to 2021 to consider the state of the art of the last 10 years and the document type to exclusively compile research papers and reviews. Then, some exclusions were made by taking into account subject areas and source titles that were not related to food and humans (subject areas: nursing, pharmacology, environmental science, chemical engineering, engineering, material science, neuroscience, veterinary, energy, economics, computer science, physics, social science, health professions, mathematics, arts, business, and psychology; source titles: journal of animal science, animal, poultry science, aquaculture, animal science journal, and in vitro cellular and developmental biology animal.). Finally, new exclusions were made after reading the titles, abstracts, and a full text revision. Figure 1 shows a scheme of the step-by-step methodology. 


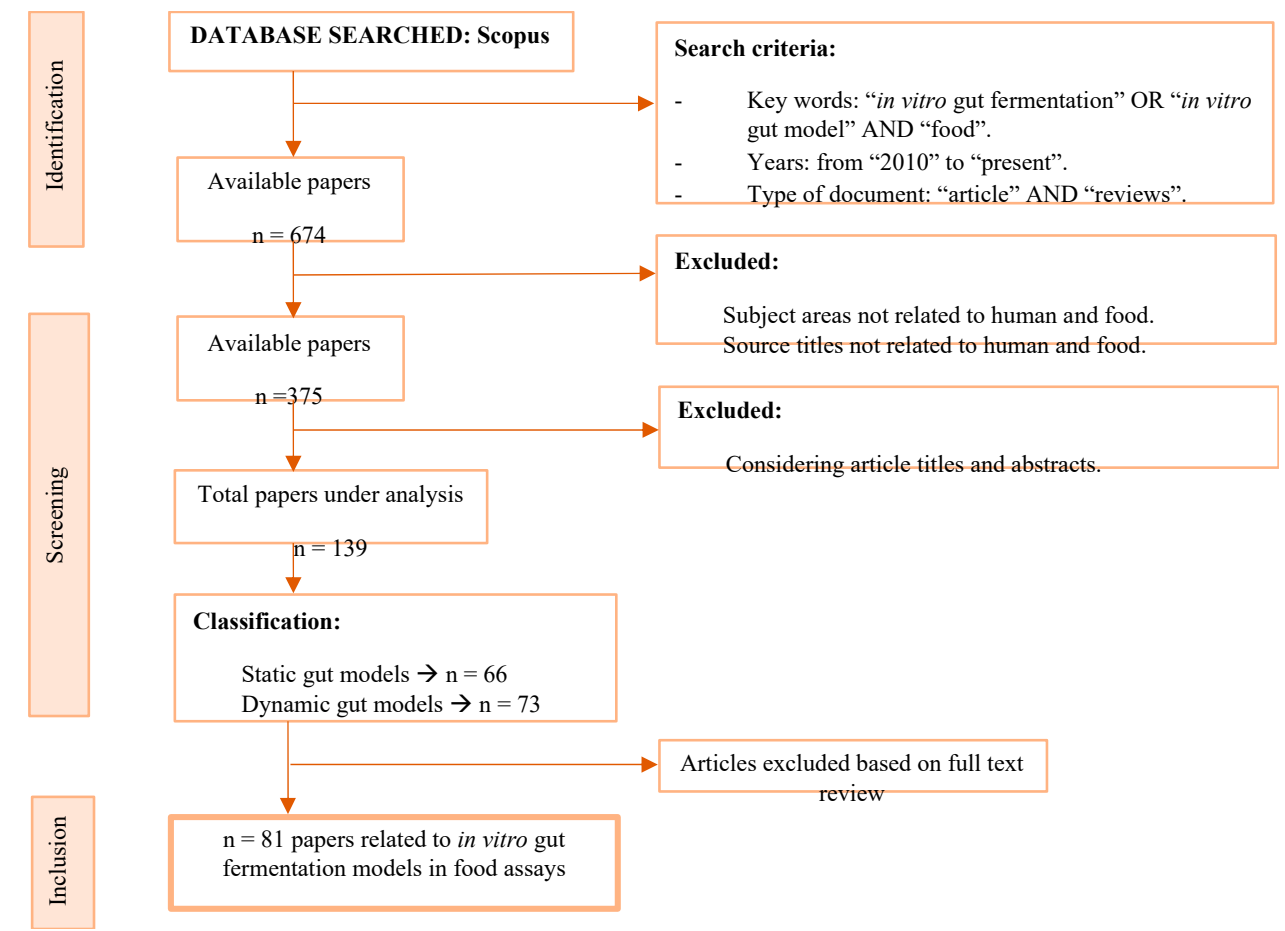

Figure 1. Flow diagram of data selection and identification process.

\section{The Colonic Fermentation Process}

The large intestine is a suitable environment ( $\mathrm{pH}$ between $6-8$ and anaerobic conditions) for the development of microorganism populations (colonic microbiota), most of which belong to the Bacteroidetes and Firmicutes phyla [15]. The main biochemical reaction occurring in the colon is fermentation, which produces a series of metabolites used by both the microorganisms and the host as a source of energy [16]. Nevertheless, it is also involved in the modulation of other body functions, such as the immune system and the brain-gut axis. The preferent substrates for the microbiota are non-digestible carbohydrates, including fibre, cellulose, hemicellulose, pectin, gums, and alginates. The colonic fermentation of these macromolecules results in short-chain fatty acid (SCFA) production, mainly acetate, butyrate, and propionate, and gas, such as hydrogen and carbon dioxide [17]. When the source of non-digestible carbohydrates is limited, the microbiota utilises protein substrates, generating sulphurated and N-nitrose compounds, ammoniac, heterocyclic amines, and branched-chain fatty acids (BCFA). On the other hand, most dietary lipids are digested and absorbed in the small intestine and do not reach the colon. However, when lipid intake is high, bile salt secretion increases, and the excess that is not absorbed along with lipids passes on to the colon and can be fermented by the microbiota, producing secondary bile salts [18]. In general terms, from the main metabolites generated by the microbiota, SCFA seem to be related to beneficial health effects, while sulphur compounds and secondary bile salts have been associated with harmful outcomes [16-18]. However, despite the acknowledgement of the important role that the microbiota plays in food digestion and the effect that food constituents have on promoting or reducing certain microbiota populations, many gaps in establishing explanations remain.

Even though some generalization about the species comprising the microbiota can be made [15], a wide diversity of factors (lifestyle, habitat, birth delivery mode, maternal nutritional status, or breastfeeding, among others) determine a specific microbiota profile in each individual. Eating habits and type of diet have a major impact [19] and can be modified, serving as a tool to modulate the microbiota composition. In particular, the effect of carbohydrates has been widely studied, as they are the main substrate for intestinal microorganisms [20]. Among them, non-digestible carbohydrates arrive in their native form to the colon and are fermented by the microbiota promoting their growth 
and activity, subsequently generating beneficial compounds for health [21]. In upper gut digestion, digestible carbohydrates are broken down into oligosaccharides, disaccharides, and monosaccharides and are absorbed before reaching the colon. Nevertheless, in highsugar diets, they can reach the colon since the absorption capacity of the small intestine is exceeded, thus causing losses in microbial diversity [22]. Similarly, protein and lipid intake can also lead to changes in microbiota composition. Diets rich in animal-origin protein and low-digestible carbohydrates lead to the microbial production of metabolites (BCFA, Nnitroso compounds) related to the increased risk of suffering from colorectal disorders [23]. In the case of fatty acids, monosaturated fatty acids and n-3 polyunsaturated fatty acids have been associated with an increase in beneficial bacteria and the production of SCFA, while diets rich in long-chain fatty acids have the opposite effect [24]. Furthermore, a wide diversity of diets is available worldwide depending on the ecosystem and cultural, economic, or agronomic considerations. This is probably the reason behind the differences in the microbiota profile observed from distinct geographical regions [20]. In this aspect, Wilson et al. (2020) contributed a large international review to compare microbiota profiles in several regions of the globe, concluding that overall, clear differences can be found depending on the diet, even more than with genetics [25].

\section{Available Colonic In Vitro Fermentation Models}

As anticipated, studying colonic fermentation in vivo entails several restrictions. Thus, colonic in vitro fermentation models can be a valid and worthwhile alternative and are increasingly used in the food research field. These models emerge with methodological advantages since they allow the possibility of sampling at any point of the process, assessing digestion of any food or nutrient and establishing its effect on microbiota profile, or determining the products generated by the microbiota metabolism $[7,11]$. On the other hand, the limitations related to in vitro models is that they do not take into consideration the contribution of the host in digestion, and thus, they could be inherently incomplete.

For the simulation of colonic fermentation in vitro, four basic elements are required: a microbial inoculum, a culture medium, a study substrate, and a bioreactor. Depending on the complexity of the conditions of the simulation or the inoculum, different types of models are currently available and are described hereafter.

\subsection{Static Colonic Fermentation Models}

Static colonic fermentation models, also called batch models, are the simplest, fastest, and least expensive way to simulate in vitro gut fermentation. Even though no specific equipment is required to perform static colonic fermentations, different ranges of complexity, from glass vessels to bioreactors, can be found. Amaretti et al. (2020) conducted colonic fermentation in an automatic bioreactor to assay the prebiotic effect of dextran over gut microbiota and its metabolite production [26]. This bioreactor operated under anaerobic conditions at corporal temperature $\left(37^{\circ} \mathrm{C}\right)$, stirring $(150 \mathrm{rpm})$, and a constant $\mathrm{pH}$ around 6.5 that was automatically controlled by adding $\mathrm{NaOH}$. Nevertheless, most of the static colonic fermentation models consist of bottles, vessels, or tubes. They are typically placed in chambers with a gas mixture $\left(\mathrm{H}_{2}: \mathrm{CO}_{2}: \mathrm{N}_{2}\right)$ to maintain the anaerobic conditions, in a shaking incubator, and at corporal temperature $\left(37^{\circ} \mathrm{C}\right)$ [27-29].

Regardless the complexity in the design, the fermentation process is performed with a faecal inoculum and a culture medium. Moreover, the compounds submitted to assay, or the non-absorbed compounds in the digesta resulting from previous digestion stages (oral, gastric, and small intestine), are incorporated into the reactor, leading to colonic fermentation. In some studies, the colonic fermentation is used to assay the effect of specific compounds (e.g., polysaccharides or oligosaccharides) on gut microbiota growth or the relative abundance of species and genera. In this type of study, the compounds to be assayed are added to the culture medium as the only source of carbon (i.e., as extracts or isolated compounds) [30-32]. In some other studies, the target is to assay the impact that foods (i.e., complex structural matrices) have on gut microbiota and the metabolites 
produced after a complete digestion process (including gut fermentation). Therefore, an upper gut digestion (oral, gastric, and small intestine) is performed prior the fermentation of the intestinal digesta with the non-absorbed components [33,34].

It is worth mentioning that static models are discontinuous, which means that there are no volumetric outputs or inputs while the in vitro colonic fermentation occurs. As such, substrates are depleted with time, and the products of the microbial metabolism are accumulated. This leads to a change in the environmental conditions (i.e., oxidationreduction potential) and eventually, the interruption of bacterial growth and activity. For this reason, the simulation length is usually short (mainly $24 \mathrm{~h}$ ), even though they could be extended to $48 \mathrm{~h}$, assuming that microorganisms need more than $24 \mathrm{~h}$ to degrade some complex structures, such as complex phenolic compounds [35]. These models are usually used to study the interaction between gut microbiota and different bioactive or functional compounds. Table 1 summarizes the applicability of the static colonic models explored in the food science and technology field over the last 10 years.

Table 1. Applicability of static in vitro colonic models in the food science and technology field from 2011 to 2021.

\begin{tabular}{lll}
\hline \multicolumn{1}{c}{ Main Objective } & \multicolumn{1}{c}{ Study Subject } & References \\
\hline & Polysaccharides and oligosaccharides from: \\
& -Fruits: Mulberry fruit. \\
& -Fungi: Craterellus cornucopioides. \\
To assay the prebiotic effect of polysaccharides & -Algae: Saccharina japonica, and Corallina pilulifera. \\
and oligosaccharides on gut microbiota and & -Plants: flowers of Camellia sinensis and A. tequilana Weber var. $\quad$ [30-32,36-42] \\
their metabolites & -Grains: Tibetan hull-less barley. \\
& -Bacteria: Weissella cibaria and Bifidobacteria. \\
& -Beans: Red kidney bean. \\
& -Tea: Fuzhuan brick tea.
\end{tabular}

To assay the prebiotic effect of some polyphenols on gut microbiota and their metabolites.
Different polyphenols from:

-Foods: cereal, meat, and dairy.

-Drinks: coffee, tea, wine, and different juices.

-New snacks: Pineapple snack bars.

-Industrial residues: Persimmon and blueberry residues.

-Pomaces: Blueberry pomace.
-Dairy, egg, fish, and meat products after boiling, frying, grilling, and roasting.

-Plant food products (alcoholic drinks, cereals, cocoa, coffee, fruits, legumes, nuts, oils, tubers, and vegetables) after boiling, frying, grilling, roasting, and toasting.

-Enzymatic modification of the cell wall integrity: cotyledon cells from pinto bean seeds.

-Extrusion: whole grain oats and wheat bran.

-Particle size manipulation: maize bran, cellulose, and whole grain oat flakes. soup.

-Edible insects: black field cricket nymphs, grass grub larvae, and wax moth larvae.

-Moringa oleifera Lam. Leaves

To assay the effect of whole foods or additives on gut microbiota and their metabolites.

-Probiotic salami.

-Tibetan hull-less barley and refined Tibetan hull-less barley.

-Spent coffee grounds.

-Sun-dried raisins.

Additives such as:

-Dietary emulsifiers: sodium CMC, P80, soy lecithin,

sophorolipids, and rhamnolipids.

To assay the gut microbiota metabolism in response to food components.
Biotransformation of polyphenols by human gut microbiota:

-Catechin.

-Flavonoid O- and C-glycosides.

$[35,60]$

-[6]-Shogaol from ginger. 
Despite of the fact that static models are useful tools to study gut microbiota-food interactions, they have limitations when it comes to mimicking gut fermentation as a dynamic process $[7,11]$; for that reason, great effort has been made to develop dynamic colonic methods.

\subsection{Dynamic Colonic Fermentation Models}

Dynamic colonic models are far more complex and expensive than the static ones. Recently, Nissen et al. (2020) presented the available dynamic colonic models according to their design, technical features, and main applicability [61]. Among them, SHIME and TIM-2 stand out for being widely applied in the food science and technology fields although SIMGI and PolyFermS are also commonly used.

These simulators have different designs so that the fermentation process can include a single (mono-stage) or several compartments (multi-stage). While only a segment of the colon is simulated (i.e., the proximal colon which is considered as ascendant and transversal) in mono-stage systems [62-64], dynamic multi-stage models can simulate up to the three regions of the colon: the ascending, transverse, and descending colon, reproducing the different in vivo environmental conditions (in terms of $\mathrm{pH}$, retention time, characteristic volume, and availability of substrates) in each of them [65-67]. Moreover, some of the dynamic in vitro models also include compartments to simulate part of the upper gastrointestinal digestion: gastric and small intestine $[68,69]$ or a dialysis system, which simulate the absorption of the metabolites produced during the fermentation process [62]. Some others allow for the simulation of the mucosal environment to colonize and mimic the gut mucosa microbiota [64,70], and finally, others are able to run two or three samples at the same time in order to have a control reference or replicates [71].

In general terms, dynamic models enable a continuous regime (substrates are continuously coming in the system while the products of the reactions are removed), allowing for the stabilization of the microbiota to the environmental conditions and reaching the steady state [72]. Once the steady state is achieved, the observed changes in the composition and function of the microbiota can be attributed to those experimental conditions, rather than to the adaptation to the environmental conditions. The stabilization period is essential in dynamic models, and it is performed before starting the experiment. The followed protocol depends on the system characteristics $[62,73,74]$. Furthermore, achieving the physiological conditions of the environment is a key aspect for reaching the proper simulated microbiota in each colonic region. Consequently, these models work at $37^{\circ} \mathrm{C}$, maintain anaerobic conditions (e.g., by periodically flushing nitrogen), control the $\mathrm{pH}$ by automatically adding $\mathrm{NaOH}$ or $\mathrm{HCl}$ to each vessel, and mixing the compartment contents (e.g., by magnetic stirring or peristaltic movements) $[73,75]$. Finally, colonic variables such as $\mathrm{pH}$, retention time, and volume not only depend on the utilized model but also on the aim or purpose of the study. For instance, in studies with PolyFermS focused on assaying both, the colonic fermentation of both the elderly [76] and children [77], the parameters in terms of $\mathrm{pH}$, retention time, and volume were set up according to an age model.

Altogether, dynamic models allow for the study of the effects of food on gut microbiota in a more complex environment that simulates the in vivo conditions better than static models and allow for the assessment of longer periods of time (e.g., one or several weeks) $[61,65,66]$. The main research objectives when using these models have been the evaluation of the prebiotic, probiotic, and symbiotic effect of some compounds on gut microbiota: Table 2 gathers the objectives and references of published studies reporting the applicability of dynamic colonic models in food science and technology fields over the last 10 years. As in the case for the in vitro simulation of digestion in the upper gut, most of the studies have focused on a food extract rather than a complete food matrix, probably due to the increased complexity of the experimental procedure and analytical determinations that food matrices imply. 
Table 2. Applicability of dynamic in vitro colonic models in the food science and technology field from 2011 to 2021.

\begin{tabular}{|c|c|c|}
\hline Dynamic Model & Main Objective and Examples & References \\
\hline \multirow{4}{*}{ SHIME } & $\begin{array}{l}\text { Assessing the probiotic effect of some bacteria: } \\
\text {-Bacteria (e.g., Lactobacillus, Bifidobacterium, or Enterococcus) carried in cheese, } \\
\text { chocolate, cereals, sausages, and drinks. } \\
\text {-Probiotic formulations (e.g., Lactobacillus, Bifidobacterium, or Bacillus) }\end{array}$ & {$[63,68,78,79,79-84]$} \\
\hline & $\begin{array}{l}\text { Assessing the prebiotic effect of some compounds: } \\
\text {-Polyphenols (e.g., black tea or red wine grape extract, t-resveratrol, and } \\
\varepsilon \text {-viniferin extract). } \\
\text {-Polysaccharides (e.g., branched fructans, arabinogalactan, } \\
\text { fructooligosaccharides, commercially available plant polysaccharide) }\end{array}$ & [85-89] \\
\hline & $\begin{array}{l}\text { Assessing the symbiotic effect (probiotic + prebiotic): } \\
\text {-Milks and beverages fermented by different microorganisms (e.g., } \\
\text { Lactobacillus) and supplemented with different compounds (e.g., passion fruit, } \\
\text { grape pomace) } \\
\text {-Probiotic and prebiotic formulations (e.g., Bifidobacterium }+3^{\prime} \text {-sialyllactose, } \\
\text { Lactobacillus + red win polyphenolic extract, Lactobacillus + } \\
\text { fructooligosaccharides, Bifidobacterium + pectins } \\
\text {-Repressing Escherichia coli colonization of the gut mucus. }\end{array}$ & {$[65,67,70,71,90-92]$} \\
\hline & $\begin{array}{l}\text { Other applications assessing the effect of: } \\
\text {-Food ingredients (e.g., Mexican "taco" from corn tortilla and black beans). } \\
\text {-Dietary emulsifiers (e.g., polysorbate } 80 \text { and carboxymethylcellulose). } \\
\text {-Antibiotics (e.g., amoxicillin, ciprofloxacin, and tetracycline). } \\
\text {-Processing (e.g., fresh and pasteurized orange juice). }\end{array}$ & {$[75,93,94]$} \\
\hline \multirow[t]{2}{*}{ TIM-2 } & $\begin{array}{l}\text { Assessing the prebiotic effect of some compounds: } \\
\text {-Polyphenols (e.g., polyphenols in pre-digested mango peel, pre-digested } \\
\text { Hibiscus sabdariffa calyces) } \\
\text {-Polysaccharides: (e.g., High- and low-acetylated } \\
\text { galactoglucomannooligosaccharides, agave fructans, xylo-oligosaccharides, } \\
\text { pectins, chicory root pulp polysaccharides) }\end{array}$ & {$[62,73,95-98]$} \\
\hline & $\begin{array}{l}\text { Other applications assessing the effect of: } \\
\text {-Supplementation with minerals (e.g., iron). } \\
\text {-Food ingredients (e.g., two types of Mexican sauces) } \\
\text {-Symbiotic effect (e.g., functional pasta with Bacillus and } \beta \text {-glucans). }\end{array}$ & [99-101] \\
\hline \multirow{3}{*}{ SIMGI } & $\begin{array}{l}\text { Assessing the probiotic effect of some bacteria } \\
\text {-Lactobacillus. }\end{array}$ & {$[66]$} \\
\hline & $\begin{array}{l}\text { Assessing the prebiotic effect of some compounds: } \\
\text {-Polysaccharides: (e.g., apple, potato, oat and psyllium fibres, hydroxypropyl } \\
\text { methylcellulose, and microcrystalline cellulose). } \\
\text {-Polyphenols: (e.g., grape pomace extracts). }\end{array}$ & {$[69,102]$} \\
\hline & $\begin{array}{l}\text { Other applications assessing the effect of: } \\
\text {-Food (e.g., red wine). }\end{array}$ & [103] \\
\hline \multirow[t]{2}{*}{ PolyFermS } & $\begin{array}{l}\text { Assessing the prebiotic effect of some compounds: } \\
\text {-Polysaccharides: (e.g., fructo-oligosaccharides, } \beta \text {-glucan, } \\
\alpha \text {-galactooligosaccharide, xylo-oligosaccharide }\end{array}$ & {$[64]$} \\
\hline & $\begin{array}{l}\text { Other uses assessing the effect of: } \\
\text {-Supplementation with minerals (e.g., iron). }\end{array}$ & [104] \\
\hline
\end{tabular}

\section{Addressing Colonic In Vitro Digestion Studies}

As anticipated above, when aiming to perform a colonic in vitro simulation, a series of prior considerations need to be considered. Among them, faecal inoculum collection and processing are of great importance. Furthermore, sampling points and analytical determinations are also essential and must be decided upon depending on the aim of the study. 


\subsection{Faecal Inoculum Collection and Preparation}

The collection of a faecal sample (from one individual) or a faecal pool (from different individuals) is one of the first steps of an in vitro colonic simulation. Faecal donors are selected according to age, gender, body mass index, presence, or absence of illness, etc., depending on the aim of the study. General considerations for donors include not having received antibiotics and prebiotics or probiotics at least some months before the faecal donations. The healthy individuals selected as control or reference groups must follow a standard diet and assure that they are free of any gastrointestinal disease. The faecal collection must be done as quickly as possible in anaerobic conditions, placing the sample in anaerobic tubes, jars, or chambers, or using devices that promote the preservation of anaerobiosis, such as OXOID ones.

After the collection, an individual faecal sample or faecal pool is mixed with a solution (e.g., phosphate buffered saline or sodium chloride) to obtain a faecal suspension or faecal slurry (e.g., $10 \% w / v$ or $20 \% w / v$ ). Then, the suspension is manually homogenised or is homogenised using a stomacher $[31,36,43,56,69]$. In addition to the previous homogenisation stage, some protocols include filtering $[27,30,54]$, or centrifugation steps $[37,65,80]$ so that the supernatant is used as faecal inoculum in the fermentation process. In addition, other protocols include the extraction of the bacterial mass from the rest of the components of the faecal sample by means of the use of iohexol $\left(\mathrm{Nycoden}^{\circledR}\right)$, which is added to the supernatant of a previously homogenised faecal suspension, causing the isolation of viable cells. After centrifugation, the sample results in a concentrated phase containing the bacteria, which can be recovered and purified with sequential rinsing with sodium chloride. This bacterial extract ensures higher amounts of microbial inoculum, but on the other hand, may cause the loss of some of the species due to the additional processing [105]. Finally, some other authors add a cryoprotective agent (glycerol) to the faecal suspension so that it can be frozen for later use $[28,95,105,106]$.

\subsection{Changes in the Microbiota Populations and Their Metabolic Response}

Either during the fermentation process or at the endpoint, samples are collected from the reactors to monitor the effect of the experimental conditions on the microbial populations and activity, which also referred to as the basal situation after inoculum stabilisation. Among them, the composition of microbial populations and the production of metabolites are of great importance when assessing the impact of food or extracts on the gut microbiota. In this context, metaomic approaches, which include metagenomics, metatranscriptomics, metaproteomics, and metabolomics have been developed and widely applied to characterize microbial communities [107]. Additionally, some other techniques are applied depending on study aim and tools availability.

Metagenomic techniques, both 16S rRNA sequencing and shotgun metagenomics, have been widely applied to determine the composition and functionality of human microbial communities. Nevertheless, metagenomics cannot elucidate which genes are expressed. In this context, metatranscriptomic and metaproteomic methods have gained weight. On the one hand, metatranscriptomic methods, which study the transcripts produced by a microbial community, reveal knowledge related to the induced/repressed genes and active/inert/dead microorganisms. The tools used for metagenomics assessment can be adapted to be used in metatranscriptomics methods, which allow for its easy integration. On the other hand, metaproteomic methods contribute to a better understanding of microbial functionality since they study the proteins produced by a microbial community. In this case, mass spectrometry (MS) is generally performed. Finally, in terms of functionality assessment, the metabolomic approach studies the metabolic pattern of a microbial community. Both mass spectrometry (MS) and nuclear magnetic resonance (NMR) are applied, but MS is preferred over NMR because of its higher sensibility. Even though it is still challenging, the integration of metaomic data could bring promising insights in terms of the human microbiota composition, functionality, and metabolite activity [108]. 
After this introduction, some of the analytical techniques used to assess in vitro gut fermentation in the last ten years were collected. Regarding the analysis of microbiota populations, $16 \mathrm{~S}$ rRNA gene sequencing is widely applied [36,37,54]. In parallel, other methodologies can be used to target or quantify specific bacteria genera or species or total bacteria, depending on the specificity of the primer used (e.g., qPCR, PCR-DGGE gel or FISH) $[26,53,80,102]$. When it comes to metabolite analysis, SCFA or BCFA production are typically analysed using gas or liquid chromatography (GC or LC) coupled with either different detectors (e.g., FID or UV) or MS [43,54,56], but when other metabolites, such as phenolic compounds, are being considered in the studies, LC techniques coupled with MS [44,102] or antioxidant tests are commonly used when studying antioxidant capacity [33]. Finally, ammonium, $\mathrm{pH}$, lactic acid, and gas volume measurements are also analysed in most of the studies $[36,65,71]$. Table 3 collects different analytical techniques that usually applied in in vitro gut fermentation studies.

Table 3. Analytical techniques used to assess in vitro gut fermentation.

\begin{tabular}{|c|c|c|}
\hline Main Objective & Analytical Determinations & References \\
\hline $\begin{array}{l}\text { To assay the prebiotic effect of } \\
\text { different polysaccharides or } \\
\text { oligosaccharides on gut microbiota } \\
\text { and their metabolites. }\end{array}$ & $\begin{array}{l}\text {-Microbiota analysis: } 16 \mathrm{~S} \text { rDNA Sequencing, qPCR, plate } \\
\text { counting with selective media or PCR-DGGE gel. } \\
\text {-SCFA analysis: GC-FID. } \\
\text {-SCFA and BCFA analysis: ion-chromatography. } \\
\text {-Metabolite analysis in fermentation broth: GC-MS or HPLC. } \\
\text {-pH measurement: pH meter. } \\
\text {-Ammonia: anion measurer connected to a selective-ion } \\
\text { electrode. } \\
\text {-Volume gas production: graduated syringe displacement } \\
\text { method. } \\
\text {-Other analysis: Reducing sugar (DNS method), viscosity } \\
\text { measurements (rheometer), or particle size measurements (laser } \\
\text { diffraction particle size analyser). }\end{array}$ & {$[26,30,31,36-38,42,54,64,69,79,80,97,109]$} \\
\hline $\begin{array}{l}\text { To assay the prebiotic effect of } \\
\text { different polyphenols on gut } \\
\text { microbiota and their metabolites. }\end{array}$ & $\begin{array}{l}\text {-Microbiota analysis: 16S rDNA Sequencing, plate counting } \\
\text { with selective media, qPCR or PCR-DGGE gel. } \\
\text {-SCFA and metabolite analysis: GC-FID, HPLC or GC-MS. } \\
\text {-Phenolic compounds analysis: HPLC-MS, UPLC-MS, } \\
\text { UHPLC-MS, or UPLC-ESI-MS/MS. } \\
\text {-Ammonium: pH/ion meter coupled to an ammonium } \\
\text { selective-ion electrode. }\end{array}$ & {$[29,43,44,46,85,86,95,99,102]$} \\
\hline $\begin{array}{l}\text { To assay the effect of sample } \\
\text { processing on antioxidant capacity } \\
\text { during gastrointestinal digestion } \\
\text { and fermentation. }\end{array}$ & $\begin{array}{l}\text {-Antioxidant tests: } \mathrm{TEAC}_{\mathrm{DPPH}} \text { assay, } \mathrm{TEAC}_{\mathrm{FRAP}} \text { assay, } \\
\text { Folin-Ciocalteu assay and TEAC } \\
\text {-Determination of phenolic acids: LC-MS or HPLC. } \\
\text {-Microbiota analysis: } 16 \mathrm{~S} \text { rDNA Sequencing. }\end{array}$ & {$[33,45,47,110]$} \\
\hline $\begin{array}{l}\text { To assay the effect of dietary } \\
\text { emulsifiers on gut microbiota and } \\
\text { its pro-inflammatory contributions. }\end{array}$ & $\begin{array}{l}\text {-SCFA analysis: GC-FID. } \\
\text {-Microbiota analysis: } 16 \mathrm{~S} \text { rDNA Sequencing and } \\
\text { metatranscriptomic analysis. } \\
\text {-Other analysis: Cell culture for flagellin detection (flagellin is a } \\
\text { virulence factor). }\end{array}$ & {$[56,75]$} \\
\hline $\begin{array}{l}\text { To assay sample processing } \\
\text { (extrusion, and diverse thermal } \\
\text { treatments) on gut microbiota }\end{array}$ & $\begin{array}{l}\text {-Gut microbiota contents: } 16 \mathrm{~S} \text { rDNA Sequencing, qPCR, or } \\
\text { FISH. } \\
\text {-SCFA analysis: HPLC or GC. }\end{array}$ & {$[50,51,53]$} \\
\hline $\begin{array}{l}\text { To assay functional foods effect on } \\
\text { gut microbiota. }\end{array}$ & $\begin{array}{l}\text {-Antioxidant assays: } \mathrm{TEAC}_{\mathrm{ABTS}} \text { assay, } \mathrm{TEAC}_{\mathrm{FRAP}} \text { assay, } \\
\text { TEAC }_{\mathrm{OH}} \text { method, TEAC } \\
\text { solid residue antioxidant capacity, Folin-Ciocalteu colorimetric } \\
\text { method. } \\
\text {-Analysis of phenolic acids: HPLC. } \\
\text {-SCFA analysis: HPLC or GC-FID. } \\
\text {-Microbiota analysis: } 16 \mathrm{~S} \text { rDNA sequencing or plate counting } \\
\text { with selective media. }\end{array}$ & {$[34,59,111]$} \\
\hline
\end{tabular}


Table 3. Cont.

\begin{tabular}{ll}
\hline Main Objective & \multicolumn{1}{c}{ Analytical Determinations } \\
\hline & References \\
& - PH measurement: pH meter. \\
To assay the probiotic effect of some & -Ammonium: Using a selective ion meter coupled to a \\
bacteria on gut microbiota. & selective-ion electrode or realising ammonium as ammonia and [68,79,81,83] \\
& titrating it with HCl. \\
& -Microbiota analysis: qPCR, plate counting, PCR-DGGE, or 16S \\
& rRNA sequencing. \\
\hline & -Microbiota analysis: 16S rDNA sequencing, plate counts, \\
& PCR-DGGE, or qPCR. \\
& -SCFA analysis: GC-FID. \\
To assay the symbiotic (prebiotic + & -Ammonium analysis: Using an anion measurer connected to a \\
probiotic) on gut microbiota & selective-ion electrode or realising ammonium as ammonia and \\
& titrating it with HCl. \\
& -Lactic acid: spectrophotometrically with an enzymatic \\
& D-/L-lactic acid Kit. \\
& -Phenolic metabolites analysis: UPLC-MS/MS. \\
\hline
\end{tabular}

qPCR: quantitative polymerase chain reaction; PCR-DGGE gel: polymerase chain reaction and denaturing gradient gel electrophoresis; GCFID: Gass chromatography and flame ionization detector; GC-MS: gas chromatography and mass spectrometry; HPLC: high-performance liquid chromatography; DNS method: 3,5-dinitrosalicylic acid method; HPLC-MS: high-performance liquid chromatography and mass spectrometry; UPLC-MS: ultra-performance liquid chromatography and mass spectrometry; UHPLC-MS: ultra-high-performance liquid chromatography and mass spectrometry; UPLC-MS/MS: ultra-high-performance liquid chromatography and tandem mass spectrometry; TEAC $_{\mathrm{DPPH}}$ assay: Trolox equivalent antioxidant capacity against $\mathrm{DPPH}$ radicals; $\mathrm{TEAC}_{\mathrm{FRAP}}$ assay: Trolox equivalent antioxidant capacity referred to reducing capacity; $\mathrm{TEAC}_{\mathrm{ABTS}}$ assay: Trolox equivalent antioxidant capacity against $\mathrm{ABTS}++$ radicals; LC-MS: liquid chromatography and mass spectrometry; $\mathrm{TEAC}_{\mathrm{OH}}$ method: Trolox equivalent antioxidant capacity against hydroxyl radicals; $\mathrm{TEAC}_{\mathrm{AAPH}}$ method: Trolox equivalent antioxidant capacity against $\mathrm{AAPH}$ - radicals; $\mathrm{GEAC}_{\mathrm{RED}}$ method: gallic acid equivalents antioxidant capacity referred to reducing capacity.

\section{Conclusions}

The connection between nutrition and health cannot be explained without considering the digestion process. In this context, in vitro models have been developed as alternative methodologies to assay the digestion process in the laboratory, avoiding in vivo study limitations and offering methodological advantages, at least for systematic or screening approaches. Those that include the oral, gastric, and small intestine stages have been widely applied, reaching a wide consensus. In contrast, in vitro simulation of the colonic stage remains without consensus, probably because of the variability and difficulty involving the reproduction and stabilization of microbiota. Nevertheless, in vitro colonic models have been developed, and different types of systems are available. In all of them, achieving the physiological conditions of the colonic environment is a key aspect for achieving the properly simulated microbiota. On the one hand, the static colonic fermentation models are simpler, faster, and less expensive, but their simulation length is shorter, and these models have limitations when it comes to mimicking gut fermentation as a dynamic process. On the other hand, dynamic one models are more complex, expensive, and longer in the simulation, and different examples can be mentioned according to the applicability, design, and protocols. Finally, this review compiles some considerations when addressing colonic in vitro digestion studies. When it comes to assessing changes in the microbiota populations and their metabolic response, metaomic approaches must be considered to characterize the microbial communities, their functionality, and the underlying food effect. Although they achieved meaningful comprehension, great efforts are being made to integrate metaomic data so they can produce promising insights. At the same time, other techniques may be applied, depending on the study's aim.

In conclusion, in vitro digestion models followed by an adequate samples assay can be considered as being suitable to generate knowledge even though there is a need to reach a consensus on the methodologies to conduct colonic in vitro digestion simulations and on the integration of the metaomic data, with the intention of determining promising insights.

Author Contributions: Conceptualization, A.A.-G., J.C.-L., A.H. and A.A.; methodology, E.V.-G., A.A.-G. and J.C.-L.; validation, E.V.-G., A.A.-G., J.C.-L., A.H. and A.A.; formal analysis, E.V.-G., A.A.-G. and J.C.-L.; investigation, E.V.-G., A.A.-G., J.C.-L., A.H. and A.A.; resources, E.V.-G., A.A.-G. 
and J.C.-L.; data curation, E.V.-G., A.A.-G. and J.C.-L.; writing-original draft preparation, E.V.-G.; writing-review and editing, A.A.-G., J.C.-L., A.H. and A.A.; visualization, A.A.-G., J.C.-L., A.H. and A.A.; supervision, A.H. and A.A. All authors have read and agreed to the published version of the manuscript.

Funding: This research received no external funding.

Institutional Review Board Statement: Not applicable.

Informed Consent Statement: Not applicable.

Data Availability Statement: Not applicable.

Acknowledgments: The authors would like to thank the Conselleria de Educació i Investigació de la Generalitat Valenciana and also the European Union ("El Fondo Social Europeo (FSE) invierte en tu futuro") for the PhD scholarship given to Andrea Asensio Grau (ACIF/2017/008) and for the post-doctoral grant given to Joaquim Calvo-Lerma (Grant number APOSTD 2019-102).This study was developed thanks to the equipment funded with the support from the Generalitat Valenciana IDIFEDER/2018/041 (PO FEDER Comunitat Valenciana 2014-2020).

Conflicts of Interest: The authors declare no conflict of interest.

\section{References}

1. Bhagavan, N.; Ha, C.-E. Gastrointestinal digestion and absorption. In Essentials of Medical Biochemistry; Academic Press: Cambridge, MA, USA, 2015; pp. 137-164. [CrossRef]

2. Engelking, L.R. Carbohydrate digestion. In Textbook of Veterinary Physiological Chemistry; Academic Press: Cambridge, MA, USA, 2015. [CrossRef]

3. Engelking, L.R. Lipid digestion. In Textbook of Veterinary Physiological Chemistry; Ademic Press: Cambridge, MA, USA, 2015. [CrossRef]

4. Bhutia, Y.D.; Ganapathy, V. Protein digestion and absorption. In Physiology of the Gastrointestinal Tract; Ademic Press: Cambridge, MA, USA, 2018; pp. 1063-1086.

5. Macfarlane, G.T.; Macfarlane, S. Models for intestinal fermentation: Association between food components, delivery systems, bioavailability and functional interactions in the gut. Curr. Opin. Biotechnol. 2007, 18, 156-162. [CrossRef]

6. Arrieta, M.-C.; Walter, J.; Finlay, B.B. Human Microbiota-Associated Mice: A Model with Challenges. Cell Host Microbe 2016, 19, 575-578. [CrossRef]

7. Venema, K.; Abbeele, P.V.D. Experimental models of the gut microbiome. Best Pract. Res. Clin. Gastroenterol. 2013, 27, 115-126. [CrossRef]

8. Calvo-Lerma, J.; Paz-Yépez, C.; Asensio-Grau, A.; Heredia, A.; Andrés, A. Impact of processing and intestinal conditions on in vitro digestion of chia (Salvia hispanica) seeds and derivatives. Foods 2020, 9, 290. [CrossRef]

9. Asensio-Grau, A.; Calvo-Lerma, J.; Heredia, A.; Andrés, A. In vitro digestion of salmon: Influence of processing and intestinal conditions on macronutrients digestibility. Food Chem. 2021, 342, 128387. [CrossRef] [PubMed]

10. Asensio-Grau, A.; Calvo-Lerma, J.; Heredia, A.; Andrés, A. Fat digestibility in meat products: Influence of food structure and gastrointestinal conditions. Int. J. Food Sci. Nutr. 2018, 70, 530-539. [CrossRef] [PubMed]

11. Payne, A.N.; Zihler, A.; Chassard, C.; Lacroix, C. Advances and perspectives in in vitro human gut fermentation modeling. Trends Biotechnol. 2012, 30, 17-25. [CrossRef]

12. Fehlbaum, S.; Chassard, C.; Schwab, C.; Voolaid, M.; Fourmestraux, C.; Derrien, M.; Lacroix, C. In vitro study of Lac-tobacillus paracasei CNCM I-1518 in healthy and Clostridium difficile colonized elderly gut microbiota. Front. Nutr. 2019, 6, 184. [CrossRef] [PubMed]

13. Mulet-Cabero, A.I.; Egger, L.; Portmann, R.; Ménard, O.; Marze, S.; Minekus, M.; Golding, M. A standardised semi-dynamic in vitro digestion method suitable for food-An international consensus. Food Funct. 2020, 11, 1702-1720. [CrossRef]

14. Brodkorb, A.; Egger, L.; Alminger, M.; Alvito, P.; Assunção, R.; Ballance, S.; Clemente, A. INFOGEST static in vitro simulation of gastrointestinal food digestion. Nat. Protoc. 2019, 14, 991-1014. [CrossRef]

15. Flint, H.J. Who inhabits our gut? In Why Gut Microbes Matter; Springer: Cham, Switzerland, 2020; pp. 47-61.

16. Wang, T.; Roest, D.I.M.; Smidt, H.; Zoetendal, E.G. "We are what we eat": How diet impacts the gut microbiota in adulthood. In How Fermented Foods Feed a Healthy Gut Microbiota; Springer: Cham, Switzerland, 2019; pp. 259-283.

17. Koh, A.; De Vadder, F.; Kovatcheva-Datchary, P.; Bäckhed, F. From Dietary Fiber to Host Physiology: Short-Chain Fatty Acids as Key Bacterial Metabolites. Cell 2016, 165, 1332-1345. [CrossRef] [PubMed]

18. Louis, P.; Hold, G.L.; Flint, H.J. The gut microbiota, bacterial metabolites, and colorectal cancer. Nat. Rev. Microbiol. 2014, 12, 661-672. [CrossRef]

19. Scott, K.P.; Gratz, S.W.; Sheridan, P.O.; Flint, H.J.; Duncan, S.H. The influence of diet on the gut microbiota. Pharmacol. Res. 2013, 69, 52-60. [CrossRef] [PubMed] 
20. Singh, R.K.; Chang, H.W.; Yan, D.; Lee, K.M.; Ucmak, D.; Wong, K.; Bhutani, T. Influence of diet on the gut micro-biome and implications for human health. J. Transl. Med. 2017, 15, 73. [CrossRef]

21. Pandey, K.R.; Naik, S.R.; Vakil, B.V. Probiotics, prebiotics, and synbiotics-A review. J. Food Sci. Technol. 2015, 52, 7577-7587. [CrossRef] [PubMed]

22. Jamar, G.; Ribeiro, D.A.; Pisani, L.P. High-fat or high-sugar diets as trigger inflammation in the microbio-ta-gut-brain axis. Crit. Rev. Food Sci. Nutr. 2020, 61, 836-854. [CrossRef]

23. Russell, W.R.; Gratz, S.W.; Duncan, S.H.; Holtrop, G.; Ince, J.; Scobbie, L.; Duthie, G.G. High-protein, re-duced-carbohydrate weight-loss diets promote metabolite profiles likely to be detrimental to colonic health. Am. J. Clin. Nutr. 2011, 93, $1062-1072$. [CrossRef]

24. Machate, D.J.; Figueiredo, P.S.; Marcelino, G.; Guimarães, R.D.C.A.; Hiane, P.A.; Bogo, D.; Pott, A. Fatty acid diets: Regulation of gut microbiota composition and obesity and its related metabolic dysbiosis. Int. J. Mol. Sci. 2020, 21, 4093. [CrossRef]

25. Wilson, A.S.; Koller, K.R.; Ramaboli, M.C.; Nesengani, L.T.; Ocvirk, S.; Chen, C.; Thomas, T.K. Diet and the hu-man gut microbiome: An international review. Dig. Dis. Sci. 2020, 65, 723-740. [CrossRef]

26. Amaretti, A.; Bottari, B.; Morreale, F.; Sardaro, M.L.S.; Angelino, D.; Raimondi, S.; Rossi, M.; Pellegrini, N. Potential prebiotic effect of a long-chain dextran produced by Weissella cibaria: An in vitro evaluation. Int. J. Food Sci. Nutr. 2020, 71, 563-571. [CrossRef]

27. Thakkar, R.D.; Tuncil, Y.E.; Hamaker, B.R.; Lindemann, S.R. Maize bran particle size governs the community composition and metabolic output of human gut microbiota in in vitro fermentations. Front. Microbiol. 2020, 11, 1009. [CrossRef]

28. Bas-Bellver, C.; Andrés, C.; Segui, L.; Barrera, C.; Jimenéz-Hernandéz, N.; Artacho, A.; Betoret, N.; Gosalbes, M.J. Valorization of Persimmon and Blueberry Byproducts to Obtain Functional Powders: In Vitro Digestion and Fermentation by Gut Microbiota. J. Agric. Food Chem. 2020, 68, 8080-8090. [CrossRef]

29. Cheng, Y.; Wu, T.; Chu, X.; Tang, S.; Cao, W.; Liang, F.; Xu, X. Fermented blueberry pomace with antioxidant prop-erties improves fecal microbiota community structure and short chain fatty acids production in an in vitro mode. LWT 2020, 125, 109260. [CrossRef]

30. Ji, X.G.; Chang, K.L.; Chen, M.; Zhu, L.L.; Osman, A.; Yin, H.; Zhao, L.M. In vitro fermentation of chitooligosaccha-rides and their effects on human fecal microbial community structure and metabolites. LWT 2021, 144, 111224. [CrossRef]

31. Zhang, X.; Liu, Y.; Chen, X.Q.; Aweya, J.J.; Cheong, K.L. Catabolism of Saccharina japonica polysaccharides and oligosaccharides by human fecal microbiota. LWT 2020, 130, 109635. [CrossRef]

32. Liu, G.; Chen, H.; Chen, J.; Wang, X.; Gu, Q.; Yin, Y. Effects of bifidobacteria-produced exopolysaccharides on human gut microbiota in vitro. Appl. Microbiol. Biotechnol. 2018, 103, 1693-1702. [CrossRef] [PubMed]

33. Navajas-Porras, B.; Pérez-Burillo, S.; Valverde-Moya, J.; Hinojosa-Nogueira, D.; Pastoriza, S.; Rufián-Henares, J. Effect of Cooking Methods on the Antioxidant Capacity of Plant Foods Submitted to in Vitro Digestion-Fermentation. Antioxidants 2020, $9,1312$. [CrossRef]

34. Gong, L.; Cao, W.; Gao, J.; Wang, J.; Zhang, H.; Sun, B.; Yin, M. Whole Tibetan Hull-Less Barley exhibit stronger effect on promoting growth of genus Bifidobacterium than refined barley in vitro. J. Food Sci. 2018, 83, 1116-1124. [CrossRef]

35. Vollmer, M.; Esders, S.; Farquharson, F.M.; Neugart, S.; Duncan, S.; Schreiner, M.; Louis, P.; Maul, R.; Rohn, S. Mutual Interaction of Phenolic Compounds and Microbiota: Metabolism of Complex Phenolic Apigenin-C- and Kaempferol-O-Derivatives by Human Fecal Samples. J. Agric. Food Chem. 2018, 66, 485-497. [CrossRef]

36. Nie, C.; Yan, X.; Xie, X.; Zhang, Z.; Zhu, J.; Wang, Y.; Wang, X.; Xu, N.; Luo, Y.; Sa, Z.; et al. Structure of $\beta$-glucan from Tibetan hull-less barley and its in vitro fermentation by human gut microbiota. Chem. Biol. Technol. Agric. 2021, 8, 1-14. [CrossRef]

37. Liu, Y.; Duan, X.; Duan, S.; Li, C.; Hu, B.; Liu, A.; Wu, Y.; Wu, H.; Chen, H.; Wu, W. Effects of in vitro digestion and fecal fermentation on the stability and metabolic behavior of polysaccharides from Craterellus cornucopioides. Food Funct. 2020, 11, 6899-6910. [CrossRef] [PubMed]

38. Jayamanohar, J.; Devi, P.B.; Kavitake, D.; Priyadarisini, V.B.; Shetty, P.H. Prebiotic potential of water extractable polysaccharide from red kidney bean (Phaseolus vulgaris L.). LWT 2018, 101, 703-710. [CrossRef]

39. Chen, G.; Xie, M.; Wan, P.; Chen, D.; Ye, H.; Chen, L.; Zeng, X.; Liu, Z. Digestion under saliva, simulated gastric and small intestinal conditions and fermentation in vitro by human intestinal microbiota of polysaccharides from Fuzhuan brick tea. Food Chem. 2018, 244, 331-339. [CrossRef] [PubMed]

40. Chen, D.; Chen, G.; Wan, P.; Hu, B.; Chen, L.; Ou, S.; Ye, H. Digestion under saliva, simulated gastric and small in-testinal conditions and fermentation in vitro of polysaccharides from the flowers of Camellia sinensis induced by hu-man gut microbiota. Food Funct. 2017, 8, 4619-4629. [CrossRef]

41. Chen, C.; Huang, Q.; Fu, X.; Liu, R.H. In vitro fermentation of mulberry fruit polysaccharides by human fecal inocula and impact on microbiota. Food Funct. 2016, 7, 4637-4643. [CrossRef]

42. Li, M.; Li, G.; Shang, Q.; Chen, X.; Liu, W.; Pi, X.; Zhu, L.; Yin, Y.; Yu, G.; Wang, X. In vitro fermentation of alginate and its derivatives by human gut microbiota. Anaerobe 2016, 39, 19-25. [CrossRef]

43. Molino, S.; Lerma-Aguilera, A.; Jiménez-Hernández, N.; Gosalbes, M.J.; Rufián-Henares, J.Á.; Francino, M.P. Enrichment of food with tannin extracts promotes healthy changes in the human gut microbiota. Front. Microbiol. 2021, 12, 570. [CrossRef] [PubMed] 
44. Del juncal-Guzmán, D.; Hernández-Maldonado, L.M.; Sánchez-Burgos, J.A.; González-Aguilar, G.A.; Ruiz-Valdiviezo, V.M.; Tovar, J.; Sáyago-Ayerdi, S.G. In vitro gastrointestinal digestion and colonic fermentation of phenolic com-pounds in UV-C irradiated pineapple (Ananas comosus) snack-bars. LWT 2021, 138, 110636. [CrossRef]

45. Gowd, V.; Bao, T.; Wang, L.; Huang, Y.; Chen, S.; Zheng, X.; Cui, S.; Chen, W. Antioxidant and antidiabetic activity of blackberry after gastrointestinal digestion and human gut microbiota fermentation. Food Chem. 2018, 269, 618-627. [CrossRef] [PubMed]

46. Bresciani, L.; Dall'Asta, M.; Favari, C.; Calani, L.; Del Rio, D.; Brighenti, F. An in vitro exploratory study of dietary strategies based on polyphenol-rich beverages, fruit juices and oils to control trimethylamine production in the colon. Food Funct. 2018, 9 , 6470-6483. [CrossRef]

47. Navajas-Porras, B.; Pérez-Burillo, S.; Valverde-Moya, Á.; Hinojosa-Nogueira, D.; Pastoriza, S.; Rufián-Henares, J.Á. Effect of cooking methods on the antioxidant capacity of foods of animal origin submitted to in vitro digestion-fermentation. Antioxidants 2021, 10, 445. [CrossRef] [PubMed]

48. Guan, N.; He, X.; Wang, S.; Liu, F.; Huang, Q.; Fu, X.; Chen, T.; Zhang, B. Cell Wall Integrity of Pulse Modulates the in Vitro Fecal Fermentation Rate and Microbiota Composition. J. Agric. Food Chem. 2019, 68, 1091-1100. [CrossRef] [PubMed]

49. Nsor-Atindana, J.; Zhou, Y.X.; Saqib, N.; Chen, M.; Goff, H.D.; Ma, J.; Zhong, F. Enhancing the prebiotic effect of cellulose biopolymer in the gut by physical structuring via particle size manipulation. Food Res. Int. 2019, 131, 108935. [CrossRef] [PubMed]

50. Pérez-Burillo, S.; Pastoriza, S.; Jiménez-Hernández, N.; D’Auria, G.; Francino, M.P.; Rufián-Henares, J.A. Effect of Food Thermal Processing on the Composition of the Gut Microbiota. J. Agric. Food Chem. 2018, 66, 11500-11509. [CrossRef]

51. Brahma, S.; Weier, S.A.; Rose, D.J. Moisture content during extrusion of oats impacts the initial fermentation metabolites and probiotic bacteria during extended fermentation by human fecal microbiota. Food Res. Int. 2017, 97, 209-214. [CrossRef] [PubMed]

52. Arcila, J.A.; Weier, S.A.; Rose, D.J. Changes in dietary fiber fractions and gut microbial fermentation properties of wheat bran after extrusion and bread making. Food Res. Int. 2015, 74, 217-223. [CrossRef] [PubMed]

53. Shen, Q.; Chen, Y.A.; Tuohy, K.M. A comparative in vitro investigation into the effects of cooked meats on the hu-man faecal microbiota. Anaerobe 2010, 16, 572-577. [CrossRef]

54. Singh, V.; Hwang, N.; Ko, G.; Tatsuya, U. Effects of digested Cheonggukjang on human microbiota assessed by in vitro fecal fermentation. J. Microbiol. 2021, 59, 217-227. [CrossRef]

55. Young, W.; Arojju, S.K.; McNeill, M.R.; Rettedal, E.; Gathercole, J.; Bell, N.; Payne, P. Feeding Bugs to Bugs: Edible Insects Modify the Human Gut Microbiome in an in vitro Fermentation Model. Front. Microbiol. 2020, 11, 1763. [CrossRef] [PubMed]

56. Miclotte, L.; De Paepe, K.; Rymenans, L.; Callewaert, C.; Raes, J.; Rajkovic, A.; Van Camp, J.; Van de Wiele, T. Dietary Emulsifiers Alter Composition and Activity of the Human Gut Microbiota in vitro, Irrespective of Chemical or Natural Emulsifier Origin. Front. Microbiol. 2020, 11, 577474. [CrossRef]

57. Dou, Z.; Chen, C.; Fu, X. Bioaccessibility, antioxidant activity and modulation effect on gut microbiota of bioactive compounds from Moringa oleifera Lam. leaves during digestion and fermentation in vitro. Food Funct. 2019, 10, 5070-5079. [CrossRef]

58. López-Barrera, D.M.; Vázquez-Sánchez, K.; Loarca-Piña, M.G.F.; Campos-Vega, R. Spent coffee grounds, an innovative source of colonic fermentable compounds, inhibit inflammatory mediators in vitro. Food Chem. 2016, 212, 282-290. [CrossRef]

59. Mandalari, G.; Chessa, S.; Bisignano, C.; Chan, L.; Carughi, A. The effect of sun-dried raisins (Vitis vinifera L.) on the in vitro composition of the gut microbiota. Food Funct. 2016, 7, 4048-4060. [CrossRef]

60. Krishnamoorthy, R.; Adisa, A.R.; Periasamy, V.S.; Athinarayanan, J.; Pandurangan, S.-B.; Alshatwi, A.A. Colonic BacteriaTransformed Catechin Metabolite Response to Cytokine Production by Human Peripheral Blood Mononuclear Cells. Biomolecules 2019, 9, 830. [CrossRef] [PubMed]

61. Nissen, L.; Casciano, F.; Gianotti, A. Intestinal fermentation in vitro models to study food-induced gut microbiota shift: An updated review. FEMS Microbiol. Lett. 2020, 367, fnaa097. [CrossRef]

62. Sáyago-Ayerdi, S.G.; Venema, K.; Tabernero, M.; Sarriá, B.; Bravo, L.L.; Mateos, R. Bioconversion by gut microbiota of predigested mango (Mangifera indica L.) 'Ataulfo' peel polyphenols assessed in a dynamic (TIM-2) in vitro model of the human colon. Food Res. Int. 2020, 139, 109963. [CrossRef]

63. Marzorati, M.; Abbeele, P.V.D.; Bubeck, S.S.; Bayne, T.; Krishnan, K.; Young, A.; Mehta, D.; DeSouza, A. Bacillus subtilis HU58 and Bacillus coagulans SC208 Probiotics Reduced the Effects of Antibiotic-Induced Gut Microbiome Dysbiosis in An M-SHIME ${ }^{\circledR}$ Model. Microorganisms 2020, 8, 1028. [CrossRef] [PubMed]

64. Poeker, S.A.; Geirnaert, A.; Berchtold, L.; Greppi, A.; Krych, L.; Steinert, R.E.; Lacroix, C. Understanding the prebi-otic potential of different dietary fibers using an in vitro continuous adult fermentation model (PolyFermS). Sci. Rep. 2018, 8, 4318. [CrossRef] [PubMed]

65. Casarotti, S.N.; Borgonovi, T.F.; Tieghi, T.D.M.; Sivieri, K.; Penna, A.L.B. Probiotic low-fat fermented goat milk with passion fruit by-product: In vitro effect on obese individuals' microbiota and on metabolites production. Food Res. Int. 2020, 136, 109453. [CrossRef] [PubMed]

66. Gil-Sánchez, I.; Cueva, C.; Tamargo, A.; Quintela, J.C.; de la Fuente, E.; Walker, A.; Moreno-Arribas, M.V.; Bartolomé, B. Application of the dynamic gastrointestinal simulator $\left(\operatorname{simgi}{ }^{\circledR}\right)$ to assess the impact of probiotic supplementation in the metabolism of grape polyphenols. Food Res. Int. 2019, 129, 108790. [CrossRef]

67. Bianchi, F.; Larsen, N.; Tieghi, T.D.M.; Adorno, M.A.T.; Kot, W.; Saad, S.; Jespersen, L.; Sivieri, K. Modulation of gut microbiota from obese individuals by in vitro fermentation of citrus pectin in combination with Bifidobacterium longum BB-46. Appl. Microbiol. Biotechnol. 2018, 102, 8827-8840. [CrossRef] 
68. Patrignani, F.; Parolin, C.; D'Alessandro, M.; Siroli, L.; Vitali, B.; Lanciotti, R. Evaluation of the fate of Lactobacillus crispatus BC4, carried in Squacquerone cheese, throughout the simulator of the human intestinal microbial ecosystem (SHIME). Food Res. Int. 2020, 137, 109580. [CrossRef] [PubMed]

69. Tamargo, A.; Cueva, C.; Alvarez, M.D.; Herranz, B.; Moreno-Arribas, M.V.; Laguna, L. Physical effects of dietary fibre on simulated luminal flow, studied by in vitro dynamic gastrointestinal digestion and fermentation. Food Funct. 2019, 10, $3452-3465$. [CrossRef] [PubMed]

70. Van den Abbeele, P.; Marzorati, M.; Derde, M.; De Weirdt, R.; Joan, V.; Possemiers, S.; Van de Wiele, T. Arabinoxylans, inulin and Lactobacillus reuteri 1063 repress the adherent-invasive Escherichia coli from mucus in a muco-sa-comprising gut model. NPJ Biofilms Microbiomes 2016, 2, 1-8. [CrossRef]

71. Barroso, E.; Van De Wiele, T.; Jiménez-Girón, A.; Muñoz-Gonzalez, I.; Martín-Alvarez, P.J.; Moreno-Arribas, M.V.; Bartolomé, B.; Pelaez, C.; Martinez-Cuesta, M.C.; Requena, T. Lactobacillus plantarum IFPL935 impacts colonic metabolism in a simulator of the human gut microbiota during feeding with red wine polyphenols. Appl. Microbiol. Biotechnol. 2014, 98, 6805-6815. [CrossRef] [PubMed]

72. Dupont, D.; Alric, M.; Blanquet-Diot, S.; Bornhorst, G.; Cueva, C.; Deglaire, A.; Mackie, A.R. Can dynamic in vitro digestion systems mimic the physiological reality? Crit. Rev. Food Sci. Nutr. 2019, 59, 1546-1562. [CrossRef]

73. Venema, K.; Verhoeven, J.; Verbruggen, S.; Keller, D. Xylo-oligosaccharides from sugarcane show prebiotic potential in a dynamic computer-controlled in vitro model of the adult human large intestine. Benef. Microbes 2020, 11, 191-200. [CrossRef]

74. Cárdenas-Castro, A.P.; Bianchi, F.; Tallarico-Adorno, M.A.; Montalvo-González, E.; Sáyago-Ayerdi, S.G.; Sivieri, K. In vitro colonic fermentation of Mexican "taco" from corn-tortilla and black beans in a Simulator of Human Microbial Ecosystem (SHIME ${ }^{\circledR}$ ) system. Food Res. Int. 2019, 118, 81-88. [CrossRef]

75. Chassaing, B.; Van De Wiele, T.; De Bodt, J.; Marzorati, M.; Gewirtz, A.T. Dietary emulsifiers directly alter human microbiota composition and gene expression ex vivo potentiating intestinal inflammation. Gut 2017, 66, 1414-1427. [CrossRef]

76. Fehlbaum, S.; Chassard, C.; Haug, M.C.; Fourmestraux, C.; Derrien, M.; Lacroix, C. Design and investigation of PolyFermS in vitro continuous fermentation models inoculated with immobilized fecal microbiota mimicking the el-derly colon. PLOS ONE 2015, 10, e0142793. [CrossRef] [PubMed]

77. Berner, A.Z.; Fuentes, S.; Dostal, A.; Payne, A.N.; Gutierrez, P.V.; Chassard, C.; Grattepanche, F.; De Vos, W.M.; Lacroix, C. Novel Polyfermentor Intestinal Model (PolyFermS) for Controlled Ecological Studies: Validation and Effect of pH. PLoS ONE 2013, 8, e77772. [CrossRef]

78. Salgaço, M.K.; Perina, N.P.; Tomé, T.M.; Mosquera, E.M.B.; Lazarini, T.; Sartoratto, A.; Sivieri, K. Probiotic infant cereal improves children's gut microbiota: Insights using the Simulator of Human Intestinal Microbial Ecosystem (SHIME $\left.{ }^{\circledR}\right)$. Food Res. Int. 2021, 143, 110292. [CrossRef] [PubMed]

79. Oddi, S.; Huber, P.; Duque, A.R.F.; Vinderola, G.; Sivieri, K. Breast-milk derived potential probiotics as strategy for the management of childhood obesity. Food Res. Int. 2020, 137, 109673. [CrossRef]

80. Roselino, M.N.; Sakamoto, I.K.; Adorno, M.A.T.; Canaan, J.M.M.; de Valdez, G.F.; Rossi, E.A.; Sivieri, K.; Cavallini, D.C.U. Effect of fermented sausages with probiotic Enterococcus faecium CRL 183 on gut microbiota using dynamic colonic model. LWT 2020, 132, 109876. [CrossRef]

81. Worametrachanon, S.; Apichartsrangkoon, A.; Chaikham, P.; Abbeele, P.V.D.; Van De Wiele, T.; Wirjantoro, T.I. Effect of encapsulated Lactobacillus casei 01 along with pressurized-purple-rice drinks on colonizing the colon in the digestive model. Appl. Microbiol. Biotechnol. 2014, 98, 5241-5250. [CrossRef]

82. Chaikham, P.; Apichartsrangkoon, A. Effects of encapsulated Lactobacillus acidophilus along with pasteurized lon-gan juice on the colon microbiota residing in a dynamic simulator of the human intestinal microbial ecosystem. Appl. Microbiol. Biotechnol. 2014, 98, 485-495. [CrossRef]

83. Sivieri, K.; Morales, M.L.V.; Adorno, M.A.T.; Sakamoto, I.K.; Saad, S.M.I.; Rossi, E.A. Lactobacillus acidophilus CRL 1014 improved "gut health" in the SHIME ${ }^{\circledR}$ reactor. BMC Gastroenterol. 2013, 13, 1-9. [CrossRef]

84. Possemiers, S.; Marzorati, M.; Verstraete, W.; Van De Wiele, T. Bacteria and chocolate: A successful combination for probiotic delivery. Int. J. Food Microbiol. 2010, 141, 97-103. [CrossRef] [PubMed]

85. Giuliani, C.; Marzorati, M.; Innocenti, M.; Vilchez-Vargas, R.; Vital, M.; Pieper, D.H.; Mulinacci, N. Dietary sup-plement based on stilbenes: A focus on gut microbial metabolism by the in vitro simulator M-SHIME ${ }^{\circledR}$. Food Funct. 2016, 7, 4564-4575. [CrossRef]

86. Kemperman, R.A.; Gross, G.; Mondot, S.; Possemiers, S.; Marzorati, M.; Van de Wiele, T.; Doré, J.; Vaughan, E.E. Impact of polyphenols from black tea and red wine/grape juice on a gut model microbiome. Food Res. Int. 2013, 53, 659-669. [CrossRef]

87. Allsopp, P.; Possemiers, S.; Campbell, D.; Oyarzábal, I.S.; Gill, C.; Rowland, I. An exploratory study into the putative prebiotic activity of fructans isolated from Agave angustifolia and the associated anticancer activity. Anaerobe 2013, 22, 38-44. [CrossRef]

88. Terpend, K.; Possemiers, S.; Daguet, D.; Marzorati, M. Arabinogalactan and fructo-oligosaccharides have a different fermentation profile in the Simulator of the Human Intestinal Microbial Ecosystem (SHIME ${ }^{\circledR}$ ). Environ. Microbiol. Rep. 2013, 5, 595-603. [CrossRef] [PubMed]

89. Marzorati, M.; Verhelst, A.; Luta, G.; Sinnott, R.; Verstraete, W.; Van De Wiele, T.; Possemiers, S. In vitro modulation of the human gastrointestinal microbial community by plant-derived polysaccharide-rich dietary supplements. Int. J. Food Microbiol. 2010, 139, 168-176. [CrossRef] 
90. Bondue, P.; Lebrun, S.; Taminiau, B.; Everaert, N.; LaPointe, G.; Hendrick, C.; Delcenserie, V. Effect of Bifidobacte-rium crudilactis and $3^{\prime}$-sialyllactose on the toddler microbiota using the SHIME ${ }^{\circledR}$ model. Food Res. Int. 2020, 138, 109755. [CrossRef] [PubMed]

91. Freire, F.C.; Adorno, M.A.T.; Sakamoto, I.K.; Antoniassi, R.; Chaves, A.C.S.D.; dos Santos, K.M.O.; Sivieri, K. Impact of multifunctional fermented goat milk beverage on gut microbiota in a dynamic colon model. Food Res. Int. 2017, 99, 315-327. [CrossRef] [PubMed]

92. Bianchi, F.; Rossi, E.A.; Sakamoto, I.K.; Adorno, M.A.T.; Van de Wiele, T.; Sivieri, K. Beneficial effects of fermented vegetal beverages on human gastrointestinal microbial ecosystem in a simulator. Food Res. Int. 2014, 64, 43-52. [CrossRef]

93. Marzorati, M.; Vilchez-Vargas, R.; Bussche, J.V.; Truchado, P.; Jauregui, R.; El Hage, R.A.; Pieper, D.H.; Vanhaecke, L.; Van De Wiele, T. High-fiber and high-protein diets shape different gut microbial communities, which ecologically behave similarly under stress conditions, as shown in a gastrointestinal simulator. Mol. Nutr. Food Res. 2016, 61, 1600150. [CrossRef]

94. Duque, A.L.R.F.; Monteiro, M.; Adorno, M.A.T.; Sakamoto, I.K.; Sivieri, K. An exploratory study on the influence of orange juice on gut microbiota using a dynamic colonic model. Food Res. Int. 2016, 84, 160-169. [CrossRef]

95. Sáyago-Ayerdi, S.G.; Zamora-Gasga, V.M.; Venema, K. Changes in gut microbiota in predigested Hibiscus sabdar-iffa L calyces and Agave (Agave tequilana weber) fructans assessed in a dynamic in vitro model (TIM-2) of the human colon. Food Res. Int. 2020, 132, 109036. [CrossRef]

96. Míguez, B.; Vila, C.; Venema, K.; Parajó, J.C.; Alonso, J.L. Potential of high-and low-acetylated galactoglucomannooligosaccharides as modulators of the microbiota composition and their activity: A comparison using the in vitro model of the human colon TIM-2. J. Agric. Food Chem. 2020, 68, 7617-7629. [CrossRef]

97. Larsen, N.; de Souza, C.B.; Krych, L.; Cahú, T.B.; Wiese, M.; Kot, W.; Hansen, K.M.; Blennow, A.; Venema, K.; Jespersen, L. Potential of Pectins to Beneficially Modulate the Gut Microbiota Depends on Their Structural Properties. Front. Microbiol. 2019, 10, 223. [CrossRef] [PubMed]

98. Ramasamy, U.S.; Venema, K.; Gruppen, H.; Schols, H.A. The fate of chicory root pulp polysaccharides during fermentation in the TNO in vitro model of the colon (TIM-2). Bioact. Carbohydr. Diet. Fibre 2014, 4, 48-57. [CrossRef]

99. Cárdenas-Castro, A.P.; Venema, K.; Sarriá, B.; Bravo, L.; Sáyago-Ayerdi, S.G.; Mateos, R. Study of the impact of a dynamic in vitro model of the colon (TIM-2) in the phenolic composition of two Mexican sauces. Food Res. Int. 2021, 139, 109917. [CrossRef]

100. Martina, A.; Felis, G.; Corradi, M.; Maffeis, C.; Torriani, S.; Venema, K. Effects of functional pasta ingredients on different gut microbiota as revealed by TIM-2 in vitro model of the proximal colon. Benef. Microbes 2019, 10, 301-313. [CrossRef]

101. Kortman, G.A.; Dutilh, B.E.; Maathuis, A.J.; Engelke, U.F.; Boekhorst, J.; Keegan, K.P.; Tjalsma, H. Microbial me-tabolism shifts towards an adverse profile with supplementary iron in the TIM-2 in vitro model of the human colon. Front. Microbiol. 2016, 6 , 1481. [CrossRef]

102. Gil-Sánchez, I.; Cueva, C.; Sanz-Buenhombre, M.; Guadarrama, A.; Moreno-Arribas, M.V.; Bartolomé, B. Dynamic gastrointestinal digestion of grape pomace extracts: Bioaccessible phenolic metabolites and impact on human gut microbiota. J. Food Compos. Anal. 2018, 68, 41-52. [CrossRef]

103. Cueva, C.; Jiménez-Girón, A.; Muñoz-Gonzalez, I.; Esteban-Fernández, A.; Gil-Sánchez, I.; Dueñas, M.; Martín-Álvarez, P.; Pozo-Bayón, M.; Bartolomé, B.; Moreno-Arribas, M. Application of a new Dynamic Gastrointestinal Simulator (SIMGI) to study the impact of red wine in colonic metabolism. Food Res. Int. 2015, 72, 149-159. [CrossRef]

104. Dostal, A.; Lacroix, C.; Bircher, L.; Follador, R.; Zimmermann, M.B.; Chassard, C. Iron modulates butyrate production by a child gut microbiota in vitro. mBio 2015, 6, e01453-15. [CrossRef] [PubMed]

105. Garcia-Mantrana, I.; Selma-Royo, M.; Alcantara, C.; Collado, M.C. Shifts on gut microbiota associated to mediterranean diet adherence and specific dietary intakes on general adult population. Front. Microbiol. 2018, 9, 890. [CrossRef] [PubMed]

106. Wang, Y.; Chen, G.; Peng, Y.; Rui, Y.; Zeng, X.; Ye, H. Simulated digestion and fermentation in vitro with human gut microbiota of polysaccharides from Coralline pilulifera. LWT 2019, 100, 167-174. [CrossRef]

107. Sergaki, C.; Lagunas, B.; Lidbury, I.; Gifford, M.L.; Schäfer, P. Challenges and Approaches in Microbiome Research: From Fundamental to Applied. Front. Plant Sci. 2018, 9, 1205. [CrossRef]

108. Zhang, X.; Li, L.; Butcher, J.; Stintzi, A.; Figeys, D. Advancing functional and translational microbiome research using meta-omics approaches. Microbiome 2019, 7, 1-12. [CrossRef] [PubMed]

109. Zamora-Gasga, V.M.; Loarca-Piña, G.; Vázquez-Landaverde, P.A.; Ortiz-Basurto, R.I.; Tovar, J.; Sáyago-Ayerdi, S.G. In vitro colonic fermentation of food ingredients isolated from Agave tequilana Weber var. azul applied on granola bars. LWT 2015, 60, 766-772. [CrossRef]

110. Gong, L.; Chi, J.; Zhang, Y.; Wang, J.; Sun, B. In vitro evaluation of the bioaccessibility of phenolic acids in different whole wheats as potential prebiotics. LWT 2018, 100, 435-443. [CrossRef]

111. Pérez-Burillo, S.; Mehta, T.; Pastoriza, S.; Kramer, D.L.; Paliy, O.; Rufián-Henares, J. Potential probiotic salami with dietary fiber modulates antioxidant capacity, short chain fatty acid production and gut microbiota community structure. LWT 2019, 105, 355-362. [CrossRef] 